\title{
Liberation Size and Beneficiation of Enyigba Lead Ore, Ebonyi State, South-East Nigeria
}

\author{
Ettu Obassi ${ }^{*}$, David Terfa Gundu², Usman Muhammad Akindele ${ }^{3}$ \\ ${ }^{1}$ Raw Materials Research and Development Council, Abuja, Nigeria \\ ${ }^{2}$ Department of Mechanical Engineering, University of Agriculture, Makurdi, Nigeria \\ ${ }^{3}$ Department of Mineral Resources Engineering, Kaduna Polytechnic, Kaduna, Nigeria \\ Email: ${ }^{*}$ ettustic@yahoo.com
}

Received 9 March 2015; accepted 30 March 2015; published 31 March 2015

Copyright (C) 2015 by authors and Scientific Research Publishing Inc.

This work is licensed under the Creative Commons Attribution International License (CC BY). http://creativecommons.org/licenses/by/4.0/

(c) $\underset{\mathrm{EY}}{\mathrm{i}}$ Open Access

\begin{abstract}
This research work centered on the determination of Liberation Size and Enrichment of Enyigba Lead Ore in Ebonyi state, Nigeria. The study reviews the fundamental operations in mineral processing i.e. the comminution process for the release and liberation of the valuable minerals particles from the ore association, and the eventual separation and concentration of the valuables from the gangue. The ore was pulverized, sieved to liberation size and beneficiated. The mesh of grind was found to be $189 \mu \mathrm{m}$, and the liberation size was established to be $63 \mu \mathrm{m}$ sieve size having the highest percentage of lead of $15.1 \%$ then enriched to $69.8 \%$ by froth flotation method and was assessed by using x-ray fluorescence (XRF). The lead concentrate by weight was obtained to be $\mathbf{8 1 . 8 0 \%}$, confirmed being of high economic grade having surpassed $60 \% \mathrm{wt} P b$ element in an ore. It is hoped that this will enhance its development to meet both local and international demand for potential investment opportunities.
\end{abstract}

\section{Keywords}

Liberation, Enyigba Lead Ore, Comminution, Beneficiation

\section{Introduction}

The extraction of specific valuable minerals from their naturally occurring ores is variously termed as "ore dressing”, “mineral dressing” and "minerals beneficiation”. For most metalliferous ores produced by mining operations, beneficiation is an important intermediate step in the transformation of natural ore to pure metal [1].

Since the goal of every mineral processing operation is to effectively separate the valuable material from the

\footnotetext{
*Corresponding author.
}

How to cite this paper: Obassi, E., Gundu, D.T. and Akindele, U.M. (2015) Liberation Size and Beneficiation of Enyigba Lead Ore, Ebonyi State, South-East Nigeria. Journal of Minerals and Materials Characterization and Engineering, 3, 125-133. 
gangue with minimum metal loss in tailings, the need to develop and employ a sustainable, effective and relatively economical method of separation is imperative. The concentration of the valuable minerals from the gangue involves exploitation of the differences in the mineral properties of the ore after effective comminution [2].

There are two fundamental operations in mineral processing namely: the release of liberation of the valuable minerals from their waste gangue mineral and the separation of these values from the gangue, this latter process being known as concentration. Therefore, the liberation of the valuable minerals from the gangue is accomplished by comminution, and one of the major objectives of comminution is the liberation or release of the valuable minerals from the associated gangue mineral at the coarsest possible particle size; if such an aim is achieved, then not only is energy saved by the reduction of the amount of fines produced, but any subsequent separation stages become easier and cheaper to operate. If high grade solid products are required, then good liberation is essential [3].

\subsection{Comminution}

Comminution in the mineral processing plant or "mill" takes place as a sequence of crushing and grinding processes. Crushing reduced grinding which can be carried out until the mineral and gangue are substantially produced as separate particles [4].

Crushing is the first mechanical stage in the process of comminution in which the main objective is the liberation of the valuable minerals from the gangue. Crushing is accomplished by compression of the ore against rigidly constrained motion path. This is contrasted with grinding which is accomplished by abrasion and impact of the ore by the free motion of unconnected media such as rods, balls or pebbles [5].

Grinding is the last stage in the process of comminution; in this stage the particles are reduced in size by a combination of impact and abrasion, either dry or in suspension in water. It is performed in rotating cylindrical steel vessel which contains a charge of loose crushing bodies called "grinding medium" which is allowed to freely move inside the mill, thus breaking the ore into particles. According to the ways by which motion is imparted to the charge, grinding mills are generally classified into two types: tumbling mills and stirred mills [6].

Most minerals are finely disseminated and intimately associated with gangue; they must be deliberately unlocked or liberated before separation can be undertaken. Therefore, the study is geared toward establishing the liberation or release of the ore from the associated gangue mineral at the coarsest possible particle size. If such an aim is achieved, then not only is energy saved by the reduction of the amount of fines produced, but any subsequent separation stages become easier and cheaper to operate.

\subsection{Particle Size Analysis}

Particle size analysis of the various products of a concentrator is a fundamental part of laboratory testing procedure. It is of great importance in determining the quality of grinding and in establishing the degree of libation of the values from the gangue at various particle sizes.

In the separation stage, size analysis of the product used to determine the optimum six of the feed process for maximum efficiency and to determine the size range at which any losses are occurring in the plant, so that they may be reduced. It is essential, therefore that methods of size analysis must be accurate and reliable, since important changes in plant operation may be made on small amount of materials used in the size test. It is also necessary that adequate care should be taken to ensure that sample is true representative of bulk materials in size analysis; same care is required for assay.

\subsection{Sieve Analysis}

Sieve analysis is one of the oldest methods of size analysis and is accomplished by passing a known weight of sample materials successively through fine sieve sizes, and then weighing the quantity of a particular size collected on each sieve size to determine the percentage by weight. Fraction sieving is carried out with wet or dry materials and the sieve is usually agitated to expose all the particles to openings.

Sieving when applied to irregular shape particle is complicated by the fact that a particle with a size near that of the nominal aperture of the test sieve may past only when presented in a favorable position. As there is an inevitable variation in the size of sieve apertures, due to irregularity of weaving, prolonged sieving will cause the larger apertures to exert an unduly large effect on the sieve analysis. Given time, every particle small enough 
could find its ways through such a few holes. The procedure is also complicated in many cases by the presentation of near-size particle which causes blinding, or obstruction of the sieve apertures, and reduces the effective area of the sieving medium. Blinding is most serious with test sieve of very small aperture size.

The process of sieving may be divided into two stages: first, the elimination of particle considerable smaller than the screen apertures, which should occur fairly rapidly; and the second, the separation of the so-called "near-size" particle which is a gradual process rarely reaching final completion. Both stages require the sieve to be manipulated in such a way that all particles have opportunities for passing the apertures, so that any blinding an aperture may be removed from it. Ideally, each small particle size should be presented individually to an aperture, but for largest sizes this is usually not practicable.

The effectiveness of a sieving test depends on the amount of materials put on the sieve (the "charge") and the type of movement imparted on the sieve; a comprehensive account of sampling techniques for sieving is given in BS 1017 [7].

Basically, if the charge is too large, the bed of materials will be too deep to allow each one a chance to meet an aperture in the most favorable position for sieving in a responsible time. The charger therefore is limited by the requirement that the end of the sieving should be appropriate to the aperture size. On the other hand, the sample must contain enough particles to be representative of the bulk, so a minimum size of sample will have to be subdivided into a number of chargers if the requirement for preventing over-loading of the sieves is to be satisfied.

\subsection{Concentration}

This is the second fundamental operation in mineral processing concerned with the separation of valuable minerals from the gangue. Once the comminution process is completed, the succeeding operations in mineral processing are taken over by what is known as separation. Regardless of the method or methods used, the aim is always the same to take a natural aggregate of minerals (an ore) and separate it into two or more mineral products. In general, the products of separation are: 1 ) the concentrate which contains the valuable minerals; and 2) the tailings which contain primarily materials of little or no value. It may be borne in mind that minerals have been liberated, either by grinding or by chemical means, and must usually be "sized" prior to their separation from each other because the efficiencies of most separation methods are improved when closely sized fractions are used.

A common feature of all separation processes is that they are imperfect-some of the materials of no value contaminate the concentrate to some extent, and some of the minerals of value are always present in the tailings in small amounts [6].

The research study will establish the particle size at which the various grains in an ore happened to be free of each other, thus setting the stage for effective and efficient separation process as well as beneficiating the ore by appropriate method of concentration.

\section{Brief Geology of Lead-Zinc Mineralization in Nigeria}

A brief look at the geology of Nigeria is important to give an idea of the geological composition of the country in terms of the ore bearing rock groupings, while the review of $\mathrm{Pb}-\mathrm{Zn}$ mineralization is intended to give credence to findings in previous studies that the Benue Trough houses some of the complex sulphide minerals including the lead-Zinc deposits under study [8].

The Geology of Nigeria is composed of four main groups known as: the Basement Complex, the Younger Granites, the Sedimentary series and the Tertiary-Recent Volcanic rocks. Precambrian rocks of the "Basement Complex", including gneisses, amphibolites, marbles and the "Older Granites" underlie large parts of Nigeria, while the post-tectonic tin-tungsten-bearing "Younger Granites" of late Paleozoic to Mesozoic age exhibit ring structures. The southwest-northeast striking Benue Trough is part of a down-faulted "failed arm" of a triple junction that formed during the separation of the African plate and the South American plate, is a NE-SW elongated Trough of subsidence which extends from the Gulf of Guinea to Lake Chad. It is considered as a part of the Pan African Mobile Zone of West Africa.

The Benue Trough is largely covered by Cretaceous continental and marine sediments. Figure 1(a) is a map of Nigeria showing the Benue Trough divided into three: the Upper, Middle and Lower Benue Trough which constitute the major $\mathrm{Pb}-\mathrm{Zn}$ mineral bearing feature in Nigeria. While Figure 1(b) shows the lead-zinc mineralization in Nigeria, which is associated with saline water intrusion in the sedimentary basins or fractured/shear zones in crystalline rocks with Lead-Zinc mineralization occurring in almost the entire 800 km length. 


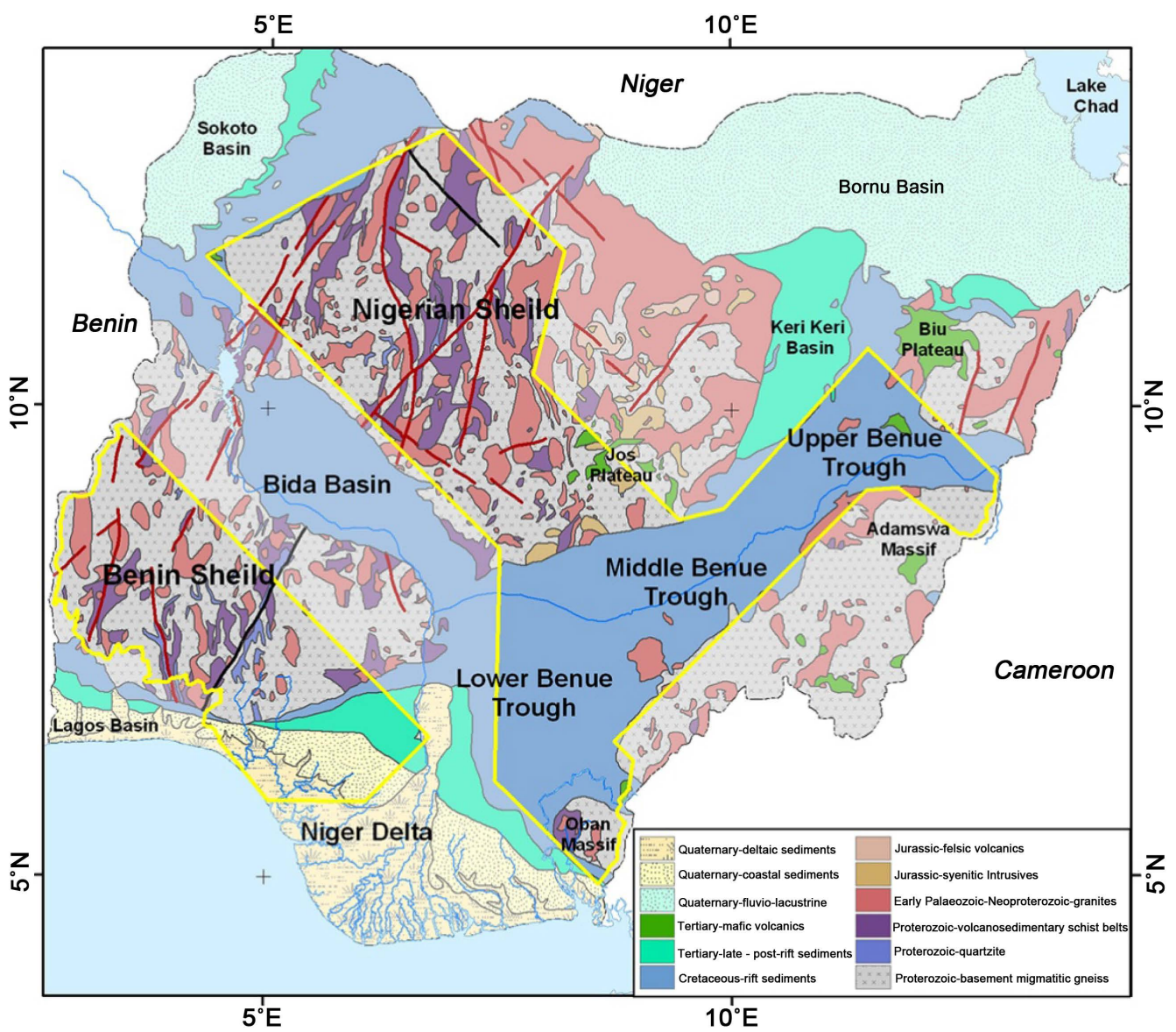

(a)

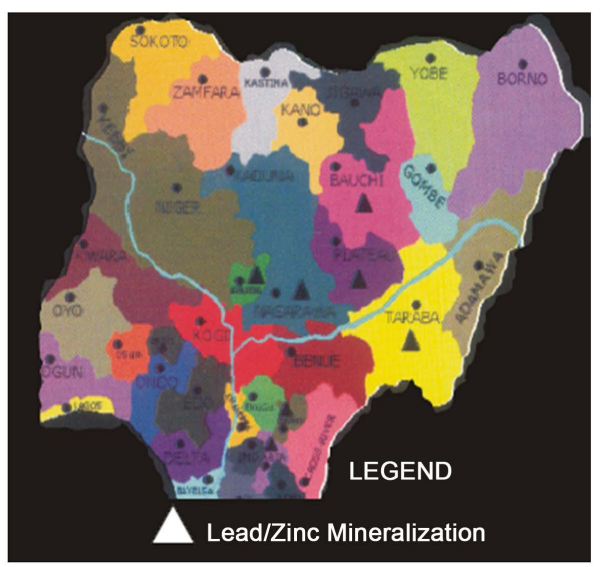

(b)

Figure 1. Maps of Nigeria showing: (a) The Benue trough and (b) Lead/Zinc mineralization in Nigeria.

The general geology of lower Benue Trough in Abakaliki area is made up of thick sequences (500 m) of slightly deformed cretaceous sedimentary rocks made up of essentially of albian shales, subordinate siltstones of the Asu River Group. There is also the presence of Volcanic and Pyroclastic materials forming elongated conical hills in the cores of the anticlinal Structures. The Lower Benue Trough houses the Ebonyi State Pb-Zn mineralization shown in Figure 2 is emplaced at a low temperature of about $140^{\circ} \mathrm{C}$ and it is made up of primarily four lodes namely Ishiagu, Enyigba, Ameri and Ameka all in the present day Ebonyi state. In the Middle Benue 


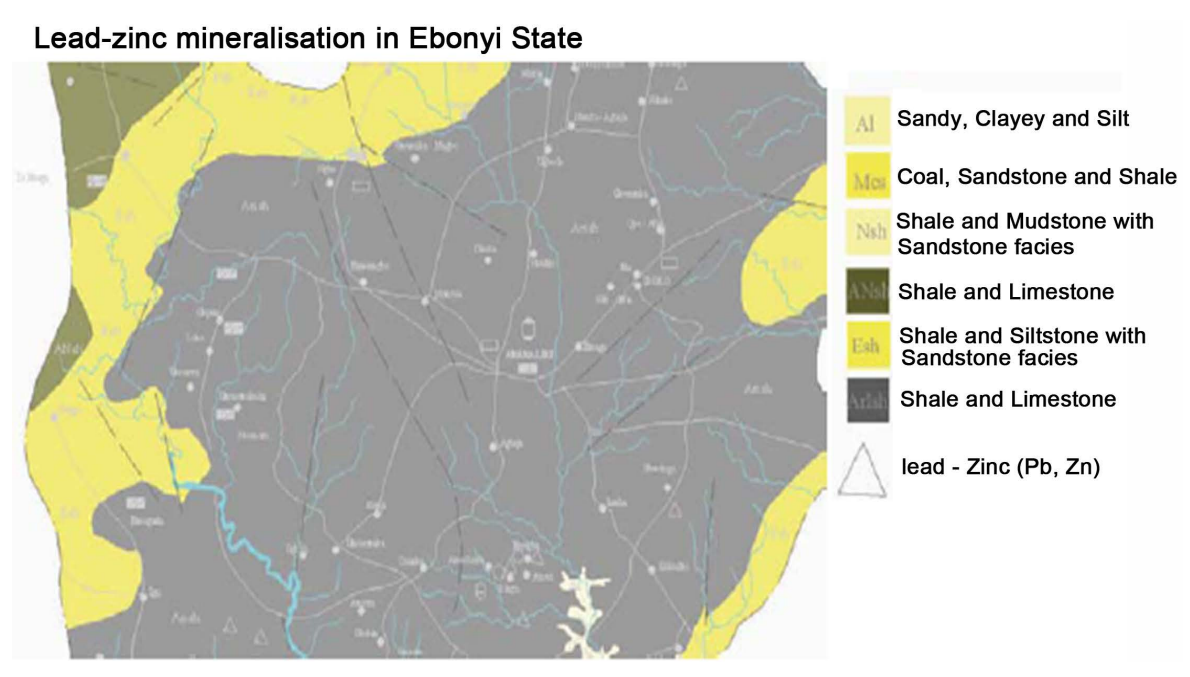

Figure 2. Map of lead/zinc mineralization in Ebonyi State. Source: Nigerian geological survey agency of the Ministry of Mines and Minerals Development (MMSD/NGSA, 2010).

Trough, veins are located mainly in Akwana and Arufu in Nassarawa state, while the Upper Benue Trough composed of the Zurak, Isimiya, Digi, Biu locations, etc in Taraba and Borno States [9]-[11].

The Ebonyi State Lead-Zinc are localized in the Enyingba area along the Northeast-Southwest trending belt of slightly deformed volcanic and sedimentary Cretaceous sequences (Albian Asu River Group) which is about 500 $\mathrm{m}$ thick, and they occur in the form of veins and veinlets associated with the host rock. Figure 2 shows map of $\mathrm{Pb}-\mathrm{Zn}$ mineralization in Ebonyi State, while Figure 3(a) and Figure 3(b) show Sketch map of the Benue Trough locating the main $\mathrm{Pb}-\mathrm{Zn}$ occurrences and map of the Enygba area showing the distribution of the mineralized fractures, respectively. The Lead-Zinc is often associated with other gangue minerals such as marcasite, pyrite, quartz, barites etc.

\section{Methodology}

The following techniques were adopted in order to determine the liberation size and beneficiation of Enyigba lead ore:

1. Sample collection

2. Sample preparation

3. Sieve analysis

4. Chemical analysis

5. Froth flotation

6. Instrumentation

\subsection{Sample Collection}

In order to have a true fraction representation of lead ore from the bulk, sample were collected from different points at different depth ranges using the random sampling techniques within the study area.

\subsection{Equipment}

The equipment used in this research work is listed below:

1. Denver crushing machine

2. Denver pulverizing machine

3. Denver sieve shaking machine

4. Denver froth flotation machine

\subsection{Sample Preparation}

The samples collected in lumps size were broken manually with sledge hammer to provide a required size ac- 


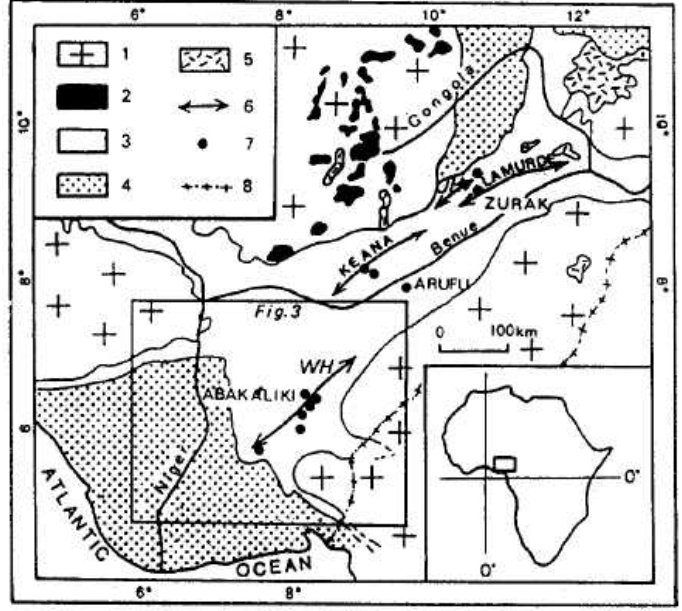

(a)

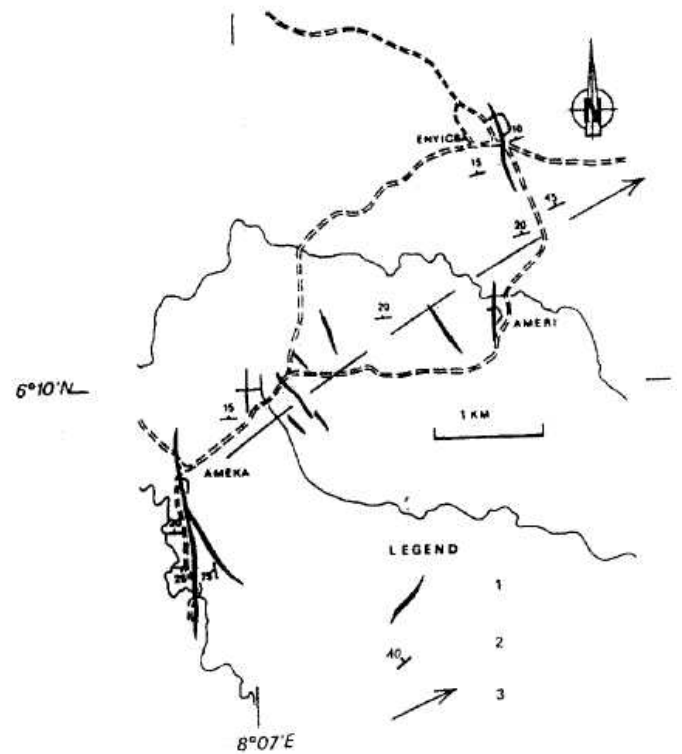

(b)

Figure 3. (a) Sketch map of the Benue Trough and Location of the main $\mathrm{Pb}-\mathrm{Zn}$ occurrences. (1) Precambrian basement; (2) Jurassic younger granites; (3) Cretaceous; (4) Undifferentiated tertiary; (5) Neogene to recent volcanic; (6) Anticlinal axis; (7) Location of mineralization; (8) International border. WH = Workum Hills, JH = Jawara Anticline; (b) Map of the Enygba area showing the distribution of the mineralized fractures. (1) Mineralized fractures; (2) Strike and dip of strate; (3) Anticlinal axis. Source: Maurin \& Benkhelil 1990.

ceptable to laboratory jaw crusher. The samples were crushed and pulverized, then coned and quartered to yield a representative sample

\subsection{Sieve Analysis}

$200 \mathrm{~g}$ of the prepared sample was subjected to sieve analysis. The arrangement of the sieves were done using a sieve scale in which the ratio of the aperture widths of adjacent sieves is the square root of two $(\sqrt{ } 2=1.414)$. Sieve sizes from $250 \mu \mathrm{m}$ to $63 \mu \mathrm{m}$ were arranged in a stack with the coarsest sieve on the top and the finest at the bottom. A tight fitting pan was placed below the bottom sieve to receive the final undersize and a lid was placed on top of the coarsest sieve to prevent escape of the sample. The arranged sieves were placed in a sieve shaker which vibrates the materials vertically. The duration of the screening was controlled to 30minutes by an automatic timer.

During the shaking, the undersize material falls through successive sieves until it is retained on a sieve having apertures which were slightly smaller than the diameter of the particle. After a successful operation each size fraction retained on each sieve was collected weighed and value recorded.

\subsection{Chemical Analysis}

Mini Pal was used which is a compact energy dispersive x-ray spectrometer designed for the elemental analysis of a wide range of samples. The system is controlled by a PC running the dedicated mini analytical software.

The mini Pal 4 version in use if PW x-ray spectrometer, which is an energy dispersive microprocessor controlled analytical instrument designed for the detection and measurement of element in a sample (solid, powders and liquids), from sodium to uranium.

The pellet is loaded in the sample chamber of the spectrometer and voltage (30 KV maximum) and a current (1 MA maximum) is applied to produce the $x$-rays to excite the sample for a present time (10 mins. in this case). The spectrum from the sample is now analyzed to determine the concentration of the element in the sample.

\subsection{Concentration by Froth Flotation}

The following equipment and materials were used: 
- Laboratory flotation machine

- Flotation cell

- Beakers

- Scraper

- Collector; sodium ethyl xanthate

- Frother; pine oil

- PH regulator; sodium carbonate(soda ash)

- PH meter

\subsection{Procedure}

a. $100 \mathrm{~g}$ of the sample was obtained from the sieve size of $63 \mu \mathrm{m}$ being the liberation size.

b. The sample was empty into the flotation cell and $2 \mathrm{~cm}^{3}$ of water added below the cell tip.

c. Impeller was start up for agitation with no air passing through the cell. Impeller speed was about $2000 \mathrm{rpm}$, having about $1 \mathrm{~cm}$ clearance from the bottom of the cell.

d. The PH was checked and adjusted to 9.5.

e. 3 drops ( $0.0015 \mathrm{~kg} /$ tonne) of collector was then added.

f. Conditioning (without air) was done for about 10 minutes after collector was added.

g. 3 drops ( $0.0015 \mathrm{~kg} /$ tonne) of frother was added before the expiration of conditioning time.

h. Air was allowed to pass through the pulp at a reasonable rate.

i. The mineralized froth was skimmed until barren froth persists.

j. The froth and tailings were filtered, washed and dried then weighed.

\section{Results and Discussions}

Results of various laboratory experiments and analysis carried out were presented and discussed below.

\subsection{Sieve Size}

It was observed from the sieve test results presented (Table 1) that $27.26 \mathrm{~g}$ of the total weight (200 g) was retained on the $250 \mu \mathrm{m}$ sieve size, $20.18 \mathrm{~g}$ on $180 \mu \mathrm{m}, 35.26 \mathrm{~g}$ on $125 \mu \mathrm{m}, 31.686 \mathrm{~g}$ on $90 \mu \mathrm{m}$ and $34.64 \mathrm{~g}$ on 63 $\mu \mathrm{m}$. From the table, the mesh of grind was calculated to be $189 \mu \mathrm{m}$.

$$
\begin{aligned}
& \text { If } 180 \mu \mathrm{m} \rightarrow 76.28 \\
& \mathrm{X} \mu \mathrm{m} \rightarrow 80 \% \\
& X=\frac{180 \times 80}{76.28}=188.8 \mu \mathrm{m} \text { at } 80 \%
\end{aligned}
$$

\subsection{Chemical Analysis}

The chemical analysis of the sample was conducted on all the five sieve sizes (Table 2). The result in its elemental form indicated that $250 \mu \mathrm{m}$ contain $9.8 \% \mathrm{~Pb}, 180 \mu \mathrm{m}$ contains $10.55 \% \mathrm{~Pb}, 125 \mu \mathrm{m}$ contains $6.99 \% \mathrm{~Pb}$, $90 \mu \mathrm{m}$ contains $14.5 \% \mathrm{~Pb}$ while $63 \mu \mathrm{m}$ contain $15.1 \% \mathrm{~Pb}$.

The result has confirmed $63 \mu \mathrm{m}$ to be liberation size of Enyigba lead ore having the highest deportment of lead in its elemental form.

\subsection{Froth Flotation}

The froth flotation results shows (in Table 3) two products; tailings with weight of $15.7 \mathrm{~g}$ and assay value of $30.7 \% \mathrm{~Pb}$ while concentrate with weight of $81.8 \mathrm{~g}$, assay value $69.8 \% \mathrm{~Pb}$ respectively. The result revealed that the ore has been enriched from $15.1 \%$ to $69.8 \% \mathrm{~Pb}$, also with 82 percent by weight lead concentrate obtained, it has been confirmed to be of economic grade having surpassed $60 \%$ wt $\mathrm{Pb}$ element in an ore [12].

\section{Conclusion and Recommendation}

\subsection{Conclusion}

From the foregoing, the research work established the mesh of grind to be $189 \mu \mathrm{m}$ for Enyigba lead ore and libe- 
Table 1. Result of sieve analysis.

\begin{tabular}{|c|c|c|c|c|c|}
\hline $\begin{array}{c}\text { Sieve size } \\
\text { Range }(\mu \mathrm{m})\end{array}$ & $\begin{array}{l}\text { Weight } \\
\text { retained (g) }\end{array}$ & $\begin{array}{l}\text { \% weight } \\
\text { retained }\end{array}$ & $\begin{array}{l}\text { Nominal } \\
\text { aperture }\end{array}$ & $\begin{array}{c}\text { Cumulative \% } \\
\text { Weight retained }\end{array}$ & $\begin{array}{l}\text { Cumulative \% } \\
\text { Weight passing }\end{array}$ \\
\hline+250 & 27.26 & 13.63 & 250 & 13.63 & 86.37 \\
\hline$-250+180$ & 20.18 & 10.09 & 180 & 23.72 & 76.28 \\
\hline$-180+125$ & 35.26 & 17.63 & 125 & 41.35 & 58.65 \\
\hline$-125+90$ & 31.68 & 15.84 & 90 & 57.19 & 42.81 \\
\hline$-90+63$ & 34.64 & 17.32 & 63 & 74.51 & 25.49 \\
\hline-63 & 50.98 & 25.49 & - & 100 & 0.00 \\
\hline
\end{tabular}

Table 2. Result of the chemical analysis of head sample in element form.

\begin{tabular}{cccccccccccc}
\hline Aperture size $(\boldsymbol{\mu m})$ & $\mathbf{S i}$ & $\mathbf{C a}$ & $\mathbf{M n}$ & $\mathbf{F e}$ & $\mathbf{N i}$ & $\mathbf{C u}$ & $\mathbf{Z n}$ & $\mathbf{A g}$ & $\mathbf{A u}$ & $\mathbf{P b}$ \\
\hline 250 & 7.67 & 0.14 & 1.00 & 10.10 & 0.02 & 0.13 & 1.00 & 1.9 & - & 9.80 \\
180 & 6.90 & 1.12 & 2.10 & 9.11 & 0.03 & 0.15 & 0.91 & - & - & 10.55 \\
125 & 5.73 & 0.10 & 0.04 & 0.38 & 0.02 & 0.01 & 0.21 & 3.00 & - & 6.99 \\
90 & 4.11 & - & 0.08 & 1.31 & 0.02 & 0.03 & 0.46 & 2.60 & - & 14.50 \\
63 & 4.92 & 0.35 & 0.05 & 11.30 & 0.03 & - & 0.02 & 1.90 & 0.08 & 15.10 \\
\hline
\end{tabular}

Table 3. Result of the froth flotation technique.

\begin{tabular}{cccccccc}
\hline \multirow{2}{*}{ Products } & Weight (g) & Weight (\%) & \multicolumn{5}{c}{ Assay Value (\%) } \\
\cline { 5 - 8 } & & & $\mathbf{P b}$ & $\mathbf{F e}$ & $\mathbf{Z n}$ & $\mathbf{S i}$ \\
\hline Feed & 100 & 100 & 15.1 & 11.30 & 0.02 & 5.22 \\
Concentrate & 81.80 & 81.80 & 69.8 & 5.68 & 0.10 & 7.45 \\
Tailings & 15.70 & 15.70 & 30.1 & 8.20 & - & 18.11 \\
\hline
\end{tabular}

ration size to be $63 \mu \mathrm{m}$ sieve size having the highest recovery of lead in its elemental form. Also further work was done on the separation using $63 \mu \mathrm{m}$ sieve size (liberation size) by froth flotation technique and the ore was enriched from $15.1 \%$ to $69.8 \% \mathrm{~Pb}$ assessed by using $\mathrm{x}$-ray fluorescence (XRF). And $82 \%$ lead concentrate by weight was obtained. It is hoped that this will enhance its development to meet both local and international demand for potential investment opportunities.

\subsection{Recommendation}

Further work needs to be done especially to determine the reserve estimates of the deposits and the possibility of metallurgical process of smelting of the concentrates obtained from the beneficiation.

\section{References}

[1] Craig, J.R. and Vaughan, D.J. (1981) Ore Microscopy and Ore Petrography, John Wiley and Sons, New York, 25.

[2] Adepoju, S.O. and Olaleye, B.M. (2000) Gravity Concentration of Silica Sand from Itakpe Iron-Ore Tailings by Tabling Operation. Nigeria Journal of Engineering Management, 2, 51-52.

[3] Wills, B.A. and Atkinson, K. (1993) Some Observation on the Tract and Liberation of Mineral Assemblies. Minerals Engineering, 6, 697-706. http://dx.doi.org/10.1016/0892-6875(93)90001-4

[4] Flavel, M.A. (1978) Control of Crushing Circuits Will Reduce Capital and Operating Costs. Mining Magazine, 207, 207. 
[5] Yan, D. and Gupta, A. (2006) Mineral Processing Design \& Operation: An Introduction. Elsevier Publisher, Netherlands, Chapter 3.

[6] Wills, B.A. (2006) Will Mineral Processing Techniques: An Introduction to the Practical Aspect of Ore Treatment and Mineral Recovery. 7th Edition, Elsevier Limited, USA.

[7] Levin, J. (1989) Observations on the Bond Standard Grindability Test and a Proposal for a Standard Grindability Test for Fine Materials. Journal of the South African Institute of Mining and Metallurgy, 89, 13-21.

[8] Federal Ministry of Mines and Steel Development (MMSD) (2010) Lead-Zinc Exploration Opportunities in NigeriaA Document Produced by the Nigerian Geological Survey Agency for the Hon Minister Ministry of Mines and Steel Development under the World Bank Assisted Project Titled "Sustainable Management of Mineral Resources Project" (SMMRP).

[9] Maurin, J.C. and Benkhelil, J. (1990) Model of Pb/Zn Mineralization Genesis in the Cretaceous Benue Trough (Nigeria): Structural, Geophysical and Geochemical Constraints. Journal of African Earth Sciences, 11, 345-349. http://dx.doi.org/10.1016/0899-5362(90)90013-5

[10] Maurin, J.C. and Lancelot, J.R. (1987) Origine des min rallsatlons de Pb-Zn de la Vallee de La Benoue (Nigerla) d'apres Lamurde Anticline composition en Pb des galenes et de l'encaissant. Mineral Depostta, 22, 99-108. http://dx.doi.org/10.1007/BF00204686

[11] Nwachukwu, S.O. (1974) Temperatures of Formation of the Southern Portion of the Benue Trough, Nigeria. Journal of Mineral, 11, 45-55.

[12] www.rosslynhillmining.com.au 